P-ISSN: 2541-6960; E-ISSN: 2549-8754

Yupa: Historical Studies Journal

Vol. 4 No. 2, 2020 (93-102)

http://iurnal.fkip.unmul.ac.id/index.php/yupa

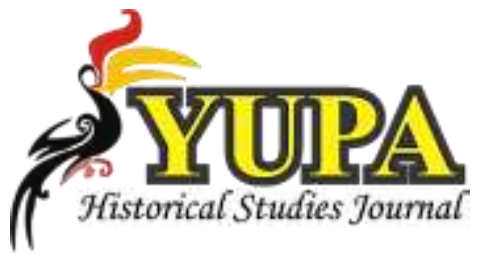

\title{
Tionghoa (Muslim) di Makassar: Studi Atas Pembaurannya dalam Bidang Budaya dan Ekonomi Pada Masa Orde Baru
}

Nurhayati $^{1}$, Aksa $^{2}$

${ }^{1}$ Sekolah Menengah Atas Negeri Keberbakatan Olahraga (SMANKO), Makassar, Indonesia

2 UIN Alauddin, Makassar, Indonesia

1 tatysejunm@gmail.com, ${ }^{2}$ aksa131288@gmail.com

\begin{tabular}{ccc}
\hline Received & Accepted & Published \\
$25 / 12 / 2020$ & $30 / 12 / 2020$ & $31 / 12 / 2020$ \\
\hline
\end{tabular}

\begin{abstract}
The Chinese who came to Makassar came from various ethnic groups and had different cultural backgrounds. The Muslim Chinese ethnic in Makassar during the New Order era had assimilated with the local community as an effort and a continuation of the government's policy of total assimilation. However, these efforts have yet to produce results that can be used as a basis for all parties on this issue. It must be admitted that there are still displeasing and discriminatory attitudes towards assimilating ethnic Chinese in Indonesia so far. However, people of Chinese descent are actually very superior in the economic field, so that they often become targets of social jealousy. The Makassar Chinese community has mingled and built interactions with the BugisMakassar community. Even some Peranakan Chinese have considered themselves to be indigenous people, even though they have not forgotten their identity.
\end{abstract}

Keywords: assimilation, Muslim Chinese, Makassar, New Order

\begin{abstract}
Abstrak Orang Tionghoa yang datang di Makassar berasal dari berbagai suku bangsa dan mempunyai latar belakang kebudayaan yang berbeda. Etnis Tionghoa Muslim di Makassar pada masa Orde baru telah melakukan pembauran dengan masyarakat setempat sebagai usaha dan kelanjutan dari kebijakan pemerintah untuk melakukan asimilasi total. Namun usaha tersebut sampai sekarang belum membuahkan hasil yang dapat dijadikan pijakan bagi semua pihak atas masalah ini. Harus diakui bahwa usaha pembauran selama ini masih ada sikap tidak senang dan diskriminatif terhadap etnis Tionghoa di Indonesia. Meski demikian, masyarakat keturunan Tionghoa justru sangat unggul dalam bidang perekonomian, sehingga seringkali mereka menjadi sasaran kecemburuan sosial. Masyarakat Tionghoa Makassar telah berbaur dan membangun interaksi dengan masyarakat Bugis-Makassar. Bahkan sebagian Tionghoa Peranakan telah menganggap dirinya sebagai orang pribumi, walaupun identitas mereka tidak serta mereka lupakan begitu saja.
\end{abstract}

Kata kunci: Pembauran, Tionghoa Muslim, Makassar, Orde Baru 


\section{PENDAHULUAN}

Dalam perjalanan sejarah bangsa Indonesia, hubungan etnis Tionghoa (Tiongkok) dengan Bangsa Indonesia telah berlangsung sejak abad ke-15 bahkan lebih jauh lagi di Sulawesi Selatan sudah ada sejak jaman Sawerigading. Kehadiran etnis Tionghoa mulai dari sejak mereka pertama kali datang dan menyebar ke berbagai wilayah Indonesia hingga sekarang menunjukkan bahwa mereka layak dianggap sebagai bagian yang sah di negara Indonesia ini. Etnis Tionghoa di Indonesia memiliki sejarah yang cukup panjang mulai dari sejak mereka pertama kali datang dan menyebar ke berbagai wilayah Indonesia hingga sekarang menunjukkan bahwa mereka layak dianggap sebagai bagian yang sah. Mereka adalah suku yang menjadi bagian dari negara-bangsa Indonesia yang memang terdiri dari berbangsa-bangsa dan bersuku-suku (Soyomukti, 2012: 155).

Sejarah keberadaan etnis Tionghoa Muslim di Nusantara dimulai ketika adanya pelayaran Laksamana Cheng Ho dari Dinasti Ming. Dia mengarungi lautan mengunjungi beberapa negara di Asia Tenggara, dan daerah lainnya termasuk Afrika Timur. Cheng Ho dengan memimpin sekitar 27 ribu kapal mengarungi lautan mengunjungi tempat tersebut termasuk Nusantara dalam tujuh kali pelayaran pada tahun 1431. Karena pelayaran Cheng Ho yang ke-6 terjadi pada tahun 14211422 dan pada waktu itu Xuan De belum naik singgasana (Yuanzhi, 2000: 73).

Masuknya etnis Tionghoa di Makassar dan Sulawesi Selatan merupakan bagian yang tidak terpisahkan dari kedatangan orang-orang Tionghoa di kepulauan Nusantara pada umumnya. Menurut Tjia Goam Lien alias Sulaiman menyatakan bahwa kedatangan etnis Tionghoa di Sulawesi Selatan bermula ketika suku Tionghoa yang berasal dari Jawa dan Kalimantan (Borneo) dengan mempergunakan perahu-perahu yang terbuat dari kayu serta beralatkan layar dari daun bambu. Kehadiran etnis Tionghoa khususnya Tionghoa Muslim telah melahirkan dinamika sosial, politik, ekonomi, budaya masyarakat yang cukup kompleks. Masa kolonialisme dan imperialisme, etnis Tionghoa menempati posisi kedua sebagai golongan kelas menengah ke atas dari masyarakat pribumi. Sementara di masa Orde Lama mereka diperhadapkan dengan status kewargaan yang dilema. Adapun masa Orde Baru menjadi masa suram bagi kehidupan Tionghoa.

Ini menghasilkan hubungan yang lebih akrab dengan masyarakat pribumi. Pembauran ini terus berlangsung hingga terjadi pernikahan dan proses asimilasi di tengah-tengah masyarakat antara etnis Tionghoa dengan masyarakat pribumi. Dalam perkembangan selanjutnya, orangorang Tionghoa mulai melakukan pembauran dengan masyarakat pribumi termasuk melakukan asimilasi dalam bidang agama berupa perkawinan campuran antara etnis Tionghoa dengan masyarakat pribumi di Kota Makassar. Dari hasil perkawinannya, anak dan keturunan mereka sering di sebut sebagai “Cina Peranakan Makassar” (Nurhayati, 2018)

Tionghoa Muslim yang peranakan sebagian ada yang yang lebih dahulu memeluk agama Islam sejak nenek moyang mereka yang melakukan perkawinan dengan orang setempat yang 
beragama Islam sehingga anak cucu mereka tetap memeluk agama leluhurnya secara turun temurun dan ada juga yang memeluk Islam karena ilham maupun karena adanya pembauran sosial, budaya dan agama, mereka setelah Muslim menjalankan ajaran Islam secara konsisten. Dalam bidang ekonomi dan perdagangan, Secara umum mata pencaharian etnis Cina Muslim adalah sebagai pedagang dan pengusaha. Walaupun telah beragama Islam, mereka mengakui bahwa ajaran leluhur mereka telah memberikan pengaruh yang sangat besar terhadap setiap aspek kehidupan Etnis Cina. Pengaruh dalam diri juga dan prilaku ekonomi mereka.

\section{METODE}

Tulisan ini adalah tulisan yang mengikuti gaya dalam penulisan sejarah. Metode yang gunakan tentunya juga menggunakan metode sejarah. Heuristik merupakan langkah awal sebagai sebuah kegiatan mencari sumber-sumber, mendapatkan data, atau materi sejarah atau evidensi sejarah (Sjamsuddin, 2007: 86). Tahapan ini dilakukan dengan cara penelitian pustaka, wawancara dan dokumentasi. Kritik sumber dilakukan untuk menyeleksi dan menguji kebenaran data yang otentik dan dapat diyakini kebenaranya serta tidak terlepas dari ranah keimiahan ilmu sejarah. Interpretasi yang dimaksud peneliti adalah memberikan makna dari data yang diperoleh dengan mengunakan data teoritis dan konsep yang digunakan penelitian dan selanjutnya menyusun fakta-fakta yang ada menjadi sebuah tulisan sejarah. Historigrafi adalah langkah terakhir dari motede sejarah.

\section{HASIL DAN PEMBAHASAN}

\section{Bentuk Pembauran di Bidang Budaya}

Perwujudan pengaruh budaya etnik Makassar dan sekitarnya atas orang Tionghoa dapat dilihat dalam tutur-sapa, pola makan dan jenis makanan, ekspresi kesenian, cara berbusana dan ragam busana, apresiasi dan ketaatan terhadap norma-norma serta nilai-nilai budaya etnik Makassar, dan aspek budaya daerah Makassar lainnya. Adanya saling pengaruh-mempengaruhi antara budaya pendatang dan budaya pribumi, dalam hal ini antara budaya etnik Tionghoa dan budaya etnik Makassar, yang telah bersetindak dalam kurun waktu yang relatif lama tersebut merupakan suatu aksioma kebudayaan.

Umumnya etnis Tionghoa membangun permukiman secara berkelompok dan berbanjar mengikuti ruas jalan, deretan rumah-rumah tersebut dibawah satu atap dan juga terdapat tempat ibadah yaitu (Klenteng). Klenteng yang merupakan tempat ibadah kepercayaan tradisional Tionghoa juga terpaksa merubah namanya dan menjadi Vihara yang merupakan tempat ibadah agama Budha sekitar tahun 1965.

Masalah pembauran di Indonesia dan di Kota Makassar secara khusus tampaknya sangat kompleks, sehingga tidak kunjung ada penyelesaian secara menyeluruh. Namun, kompleksitas 
persoalan pembauran juga ada dampak positifnya, yakni munculnya berbagai tawaran konsep dan pemikiran untuk mencari jalan keluar pemecahannya. Menurut beberapa sumber, untuk menyelesaikan atau mencari jalan keluar dari masalah pembauran di Indonesia dan di Kota Makassar adalah melalui proses asimilasi dalam kehidupan sosial dan budaya.

Pembauran akan berjalan dengan lancar jika unsur persamaan identitas dengan kelompok mayoritas, seperti nama dan panggilan untuk seorang anggota etnis Tionghoa diganti menjadi nama Indonesia atau nama yang mencirikan orang Makassar. Nama-nama yang dipakai bisa diambil dari nama-nama yang lazim yangdipergunakan oleh pemeluk agama Islam, yang biasa dipakai oleh umat Kristen, atau nama- nama yang berbau asing tergantung kepada individu atau etnis Tionghoa yang bersangkutan. Perubahan nama itu bisa dilihatmisalnya pada mereka yang berpindah agama dan masuk agama Islamserta menggunakan nama Islam, begitu juga dengan mereka yangmemeluk agama lainnya.

Beberapa orang yang beretnis Tionghoa baik yang beragama Islam maupun agama yang lain telah memiliki nama-nama panggilan yang mencirikan bahwa mereka bagian dari nama yang diambil darri budaya setempat. Walaupun disadari bahwa sebagian dari mereka pemberian nama seperti hanya sebagai panggilan saja, akan tetapi mereka umumnya menyukai nama-nama yang mengandung nilai dan budaya Bugis Makassar. Beberapa diantaranya yaitu Bapak Arwan Tjahaya di dengan nama panggilan Daeng Naba artinya orang yang baik, Johanna Usagani dengan Sebutan Nona Bungko artinya anak Bungsu dan Ritman Widarso dengan nama panggilannya Daeng Buang. Nama-nama seperti yang telah disebutkan di atas adalah dari sekian banyak orang-orang etnis Tionghoa yang memakai nama-nama yang mengandung unsur budaya Makassar.

Dilihat dari segi budaya, Etnis Tionghoa adalah salah satu etnis yang sangat kuat dalam mempertahankan dan menjaga tradisi dan budaya nenek moyangnya. Maka tidak mengherankan ketika tradisi dan budaya nenek moyangnya mereka pertahankan setelah mereka alih agama (konversi ke agama Islam). Justru budaya awalnya tetap mereka lestarikan dan direkonstruksi kembali nilai-nilai yang menjadi semangat awal tradisi dan budaya tersebut. Beberapa diantaranya adalah tradisi Ceng-Beng/ Ceng Ming dan tradisi Imlek. Tradisi Ceng Beng atau Ceng Ming adalah salah satu yang sering dilakukan oleh warga Tionghoa untuk datang ke kuburan orang tua atau leluhurnya. Tradisi ini dimaksudkan untuk membersihkan dan sekalian bersembahyang di makam sambil membawa buah-buahan, kue-kue, makanan dan karangan bunga. Upaya Ceng Beng tidak hanya Tionghoa yang beragama Konghucu, namun juga dihadiri oleh Tionghoa yang beragama Budha dan Kristen.

Setelah mereka melakukan Konversi agama awal mereka ke agama Islam, mereka tetap mempertahankan budaya itu. Ziarah ke makam atau kuburan orang tua tidak ada hubungannya dengan berhala ataupun pelanggaran atas keyakinan keislamannya karena tatacara pelaksanaan ziarah kubur bisa disesuaikan dengan keyakinan masing-masing. Sebagaimana yang 
dikemukakan oleh Jhon Adam bahwa penghormatan kepada orang tua tidak pernah dilarang bahkan diperintahkan dalam agama apapun selama penghormatan kepada orang tua dilakukan dalam kapasitasnya sebagai hamba Allah. Sebagai mahluk Allah, orang tua dan leluhur tidak mampu mendatangkan kebaikan dan keburukan kepada keturunanannya kecuali atas ijin Allah SWT (wawancara Rosmini dkk dengan Jhon Adam dalam Rosmini, 2016: 96).

\section{Bentuk Pembauran di Bidang Budaya}

Sejak permulaan abad XVII orang Tionghoa merupakan kelompok yang mulai memainkan peranan penting dan menjadi kukuh ketika tahun 1618, mereka secara resmi membuka kantor perwakilan dagang di Somba Opu. Meskipun tidak cukup bukti untuk mengetahui jumlah mereka tetapi besar kemungkinan pertumbuhannya semakin signifikasidi awal abad itu. Namun menjelang dua dekade orang-orang Belanda, Inggris, Spanyol dan Denmark juga telah membuka kantor dagang di Somba Opu mulai berhasil menjalin kerja sama dengan penduduk Tionghoa yang menetap, yang memungkinkan mereka berpartisipasi dalam perdagangan melalui pengumpulan barang-barang lokal yang ditukar dengan barang tekstil.

Komoditas yang ada mendapat penawaran yang besar dari pedagang dan penduduk pribumi, sebaliknya pedagang pribumi khususnya yang berasal dari Sulawesi Selatan memegang peranan penting dalam penjualan produksi dari kepulauan yang mendapat permintaan dari Tionghoa Seperti, taripang, agar-agar, kerang mutiara, sirip ikan, sarang burung, kayu cendana dan lainnya. Komoditi-komoditi yang dicari oleh pedagang Tionghoa yang melakukan pelayaran niaga kekawasan tersebut, pelayaran yang telah menjangkau ke seluruh wilayah melalui poros Jawa-Makassar-Maluku-Tionghoa dan kepulauan lain di Indonesia bagian timur, kepentingan yang sama menyebabkan dua kelompok pedagang ini saling membutuhkan dan mencari tempat dimana mereka dapat berniaga (Effendy,1995:114-115).

Orang-orang Indonesia keturunan Tionghoa jelas sangat bermanfaat dalam bidang ekonomi (Mahfud, 2013: 273). Memang, pada umumnya warga keturunan Tionghoa sebagian besar menggeluti dunia perdagangan sebagai aktivitas kesehariannnya, dan selebihnya bekerja dalam sektor ekonomi lainnya seperti perbankan, indutri, jasa kontruksi dan kepariwisataan. Mereka tersebar dalam Kota Makassar, terutama di pusat-pusat perdagangan (pusat pertokoan atau pasar-pasar), di sekitar pelabuhan (Jalan Nusantara, Jalan Sulawesi dan sekitarnya).

Hampir dapat dikatakan bahwa mereka umumnya dikenal sebagai pedagang yang ulet dan banyak yang berhasil, karena pada masa lalu orang Tionghoa secara politis sudah dibatasi ruang gerak dan wilayah jelajah mata pencahariannya, terutama setelah mereka dituding sebagai pendukung partai komunis di Indonesia akhir 1950-an sampai 1960-an. Mereka tidak diberi peluang untuk menjadi pegawai negeri, tentara maupun polisi apalagi duduk dalam pemerintahan ataupun dalam parlemen. Kalaupun ada, tentu saja dengan melalui jalur-jalur khusus, memiliki prestasi, atau kemampuan yang luar biasa. Terlebih lagi setelah mereka dilarang 
untuk tinggal (bermukim) jauh ke pelosok desa, sehingga bakat tani atau nelayan yang mungkin termiliki menjadi sirna tidak tersalurkan. Dengan kondisi yang demikian, mereka kemudian berusaha dan belajar dengan keras dalam hal perdagangan. Hal ini hampir dialami oleh orang Tionghoa di seluruh wilayah Indonesia kecuali di beberapa tempat tertentu.

Tionghoa peranakan di Makassar hidup seperti kebanyakkan orang Tionghoa lainnya, banyak yang menjadi pengusaha akan tetapi tidak sedikit pula yang karena pendidikannya mereka bisa menjadi guru di sekolah-sekolah katolik, menjadi dosen, menjadi dokter yang bekerja di rumah-rumah sakit dan membuka praktek. Demikian halnya dengan Tionghoa muslim yang kebanyakan dari Tionghoa pernakan, dalam dunia usaha mereka lebih banyak menggeluti usaha kecil dan menengah (Rosmini dkk, 2016:62)

Dunia usaha orang Tionghoa peranakan tidak banyak yang mencapai kehidupan sejahtera seperti kebanyakkan Tionghoa totok. Hanya beberapa Tionghoa peranakan saja yang dapat menikmati hidup mewah, karena usaha merekapun cukup besar, misalnya menjadi pengusaha dialer motor dan mobil, ekspor-impor, real estate, hotel dan restoran, travel, perbankan, dan lain sebagainya (Bahrun, 2003: 84). Pekerjaan percetakan sudah lama dikenal dalam masyarakat Peranakan Makassar. Untuk pekerjaan jasa, sejak masa Belanda, masyarakat Peranakan telah banyak bekerja diberbagai kantor cabang atau perusahaan milik orang Eropa dan meneruskan pekerjaannya di agen-agen perusahaan asuransi atau menjadi pegawai bank (Wirawan, 2013: 234)

Toko-toko orang Tionghoa di Makassar dibangun secara berkelompok mengikuti ruas jalan. Jenis jualan mereka pun seakan-akan sudah ditentukan dalam kelompok-kelompok tersebut. Misalnya, toko-toko atau pedagang-pedagang alat-alat motor dan mobil terdapat di jalan Veteran Utara. Warga Tionghoa yang berjualan alat elektronik terdapat di jalan Bulu Saraung. Sedangkan di jalan Sulawesi terdapat sejumlah pedagang makanan dan buah-buahan. Di jalan Somba Opu, mereka berkelompok secara eksklusif dan berdagang aneka macam barang dagangan, berupa pakaian, perhiasan dari perak, dan emas, tas, sepatu, karpet dan berbagai alatalat rumah tangga, aneka jam, jamu, makanan dan sebagainya.

Berkat etos kerja dan sikap hemat di masa lalu yang cukup tinggi, anak cucu mereka bisa hidup dalam kondisi yang lebih baik sekarang. Kemiskinan yang dahulu pernah dicitrakan pada warga Tionghoa di Makassar kini tergantikan dengan gaya hidup yang serba mewah dan glamour. Mall, hotel, dan toko-toko besar di pusat-pusat-pusat kota di Makassar adalah hampir semua milik warga Tionghoa.

Kehidupan mewah dan penguasaan modal besar lebih didominasi oleh warha Tionghoa totok. Sedangkan warga Tionghoa yang berkonversi ke Islam lebih banyak dari Tionghoa peranakan. Tionghoa totok adalah Tionghoa yang lahir di negera lain dan sama sekali berdarah asing, ia berbahasa Tionghoa peranakan adalah yang dilahirkan dan dibesarkan di Indonesia yang 
kebudayaannya telah dipengaruhi oleh kebudayaan Indonesia, mereka memakai bahasa Indonesia dan bahasa daerah Makassar sebagai bahasa sehari-hari dan pada umumnya telah hilang kepandaiannya menggunakan bahasa Mandarin. Mereka lebih menampakkan budaya Indonesia dari pada budaya Tionghoa. Bahasa Tionghoa rupanya tidak pernah populer dan tidak pernah dipakai sebagai bahasa sehari-hari oleh kaum Tionghoa peranakan.

Warga Tionghoa totok lebih suka bekerja untuk diri sendiri dan sebagian besar berkecimpung dalam dunia usaha. Tionghoa peranakan memilih pekerjaan kejujuran atau staf administrasi pada perusahaan-perusahaan besar. Pemilihan bidang pekerjaan ini mencerminkan perbedaan yang menyolok dalam oreantasi nilai. Tionghoa totok lebih menghargai kekayaan, kehematan, kerja, kepercayaan, pada diri sendiri dan keberanian (Rosmini dkk, 2016:61-62). Sedangkan kaum lebih menghargai penikmatan hidup, waktu senggang, kedudukan sosial dan perasaan terjamin. Dalam banyak hal, kaum peranakan ini mengembangkan kebudayaan sendiri, yang tidak hanya merupakan kohabitasi kebudayaan Tionghoa dan lokal tetapi telah menyerupai orang Makassar, sekalipun masih bisa dibedakan dari penduduk setempat. Meskipun demikian, apa pun perubahan yang terjadi pada diri orang Tionghoa, "mereka tetap dilihat sebagai sub etnis yang "tidak pernah beranjak meninggalkan tradisi dan peradaban Tionghoa (Effendy, 2004:219)

Umumnya mereka mempunyai bakat berdagang, serta berani dalam melakukan spekulasi dan bekerja keras. Sudah tentu, tidak hanya dalam bidang perdagangan dengan berdirinya tokotoko milik Tionghoa di pinggir-pinggir jalan, tetapi generasi muda mereka juga mempunyai talenta atau kecerdasan yang lebih unggul dari pada penduduk pribumi (Muhammad, 2011:101) Dalam perdagangan mereka berbaur dengan pedagang-pedagang pendatang lainnya, seperti orang Bugis, orang keturunan India, keturunan Arab, keturuan Pakistan, dan sebagainya juga tentunya pedagang pribumi (orang Makassar) (Bahrum, 2003: 83)

Sistem perdagangan warga Tionghoa di Makassar selanjutnya menggunakan patron-klien dalam melakukan kerja sama dengan pengusaha pribumi. Kerja sama itu meliputi modal, managemen, ketenagakerjaan, sampai pada level terendah. Pedagang-pedagang Tionghoa kebanyakan bertindak patron yakni sebagai pedagang klontongan yang melakukan penjualan dalam jumlah partai besar di pasar Butung atau di pasar sentral. Sementara pedagang pribumi bertindak sebagai clien para pedagang Tionghoa yaitu pedagang yang menjual secara eceran di dalam pasar Butung dan di pasar-pasar tradisional lainnya. Berdasar pada hubungan persahabatan dan prinsip kepercayaan, para pedagang eceran dari warga pribumi memperoleh harga yang relatif murah bahkan dipercaya memperoleh barang harga kredit (Rosmini dkk, 2016:61-62).

Ketika menjalangkan usaha dagangnya, orang Tionghoa tetap membangun relasi dengan para pedagang keturunan lainnya. Begitu juga dengan pedagang lokal yang mendapatkan barang dari pengusaha Tionghoa, kemudian barang-barang tersebut dijual belikan di daerah-daerah 
sekitar kota Makassar, dan bahkan sampai di pedesaan yang jauh. Dengan membangun relasi dengan berdasar pada saling mempercayai satu sama lain dalam dunia usaha, telah mempererat hubungan antara pedagang Tionghoa dengan pedagang lain. Hubungan ini bahkan sudah terjalin sekian lama sebelumnya.

Masyararakat suku Makassar masih ditemukan di dalamnya bekas-bekas komunitas orang Tionghoa yang bermukim di pelosok misalnya di daerah Sanro Bone, Galesong, di Kabupaten Takalar. Orang-orang Tionghoa tersebut dahulu dikenal pula sebagai pedagangpedagang yang ulet yang memasok barang-barang kebutuhan masyarakat dan raja di sana. Selain mereka bermukim mereka pun banyak yang melakukan perkawinan dengan orang setempat atau dengan keluarga bangsawan. Jika keluarga yang mereka kawini adalah keluarga petani dan memiliki tanah yang luas, orang Tionghoa tersebut akan pula terlibat dalam kegiatan pertanian sebagai mata pencaharian kedua (sampingan). Akan tetapi mata pencaharian utamanya adalah berdagang.

Tingkat adaptasi dan integrasi orang Tionghoa di Kota Makassar menunjukkan banyaknya pengusaha yang melakukan usaha bersama dengan pengusaha pribumi. Jika diteli lebih lanjut kerja samaa tersebut meliputi modal, manajemen, ketenagakerjaan, sampai pada level terendah. Pedagang-pedagangan Tionghoa tersebut sudah memiliki pelanggang-pelanggang tertentu yang terdiri dari pada pedagang eceran termasuk pedagang yang berjualan di luar Kota Makassar. Hubungan antar pedagang dan pelanggangnya tersebut tidak hanya dalam hubungan kerja (dagang) tetapi juga mengarah pada pertalian persahabatan atau persaudaraan yang dalam hubungan dagang mereka bisa saling percaya, oleh karena sudah dianggap sebagai saudara maka seorang pedagang eceran dapat memperoleh korting (harga yang relatif murah), dan dapat memperoleh kredit barang dari pedagang Tionghoanya lantaran kepercayaan itu.

Sebagian orang Tionghoa peranakan juga berjualan sebagai pedagang eceran di pasarpasar atau di rumah toko mereka yang tersebar di segala penjuru Kota Makassar. Meskipun demikian, pengaturan jenis dagangan dalam wilayah Kota Makassar tidak seketat kota-kota besar yang ada di pulau Jawa, seperti Jakarta, Bandung, dan Surabaya. Setiap wilayah kota akan ditemukan masing-masing jenis dagangan tertentu dan tidak diperbolehkan adanya campur baur. Pedagang elektronika akan berkumpul dengan sesamanya dan tidak boleh ada Departemen Store yang menjual bahan pakaian di sekitarnya. Di Makassar, sekalipun pada ruas-ruas jalan tertentu kelihatan adanya spesifikasi akan tetapi masih ditemukan campur baur (Bahrum, 2003: 85-87).

\section{KESIMPULAN}

Pengaruh budaya etnik Makassar dan sekitarnya atas orang Tionghoa dapat dilihat dalam tutur-sapa, pola makan dan jenis makanan, ekspresi kesenian, cara berbusana dan ragam busana, apresiasi dan ketaatan terhadap norma-norma serta nilai-nilai budaya etnik Makassar, dan aspek 
budaya daerah Makassar lainnya. Budaya pendatang (budaya etnik Tionghoa Muslim) dan budaya pribumi (budaya etnik Makassar) saling pengaruh-mempengaruhi, dan telah bersetindak dalam kurun waktu yang relatif lama tersebut merupakan suatu aksioma kebudayaan. Etnis Tionghoa adalah salah satu etnis yang sangat kuat dalam mempertahankan dan menjaga tradisi dan budaya nenek moyangnya. Maka tidak mengherankan ketika tradisi dan budaya nenek moyangnya mereka pertahankan setelah mereka alih agama (konversi ke agama Islam). Justru budaya awalnya tetap mereka lestarikan dan direkonstruksi kembali nilai-nilai yang menjadi semangat awal tradisi dan budaya tersebut. Dalam banyak hal, kaum peranakan (tionghoa Muslim) ini mengembangkan kebudayaan sendiri, yang tidak hanya merupakan kohabitasi kebudayaan Tionghoa dan lokal tetapi telah menyerupai orang Makassar, sekalipun masih bisa dibedakan dari penduduk setempat

Dalam bidang ekonomi, orang-orang Tionghoa muslim sebagian besar menggeluti dunia perdagangan sebagai aktivitas kesehariannnya, dan selebihnya bekerja dalam sektor ekonomi lainnya seperti perbankan, indutri, jasa kontruksi dan kepariwisataan. Mereka tersebar dalam Kota Makassar, terutama di pusat-pusat perdagangan (pusat pertokoan atau pasar-pasar), di sekitar pelabuhan (Jalan Nusantara, Jalan Sulawesi dan sekitarnya). Tionghoa peranakan di Makassar hidup seperti kebanyakkan orang Tionghoa lainnya, banyak yang menjadi pengusaha akan tetapi tidak sedikit pula yang karena pendidikannya mereka bisa menjadi guru di sekolahsekolah katolik, menjadi dosen, menjadi dokter yang bekerja di rumah-rumah sakit dan membuka praktek. Demikian halnya dengan Tionghoa muslim yang kebanyakan dari Tionghoa pernakan, dalam dunia usaha mereka lebih banyak menggeluti usaha kecil dan menengah. Tionghoa (muslim) peranakan memilih pekerjaan kejujuran atau staf administrasi pada perusahaanperusahaan besar. Berbeda dengan Tionghoa totok yang lebih suka bekerja untuk diri sendiri dan sebagian besar berkecimpung dalam dunia usaha. Pemilihan bidang pekerjaan ini mencerminkan perbedaan yang menyolok dalam orientasi nilai

\section{REFERENSI}

Bahrum, Shaifudin. 2003. Cina Peranakan Makassar: Pembauaran Melalui Perkawinan Antar Budaya. Makassar: Yayasan Baruga Nusantara.

Effendy, Muslimin A.R. 2004. Tionghoa-Makassar di tengah Pusaran Sejarah. Dalam Sutherland, Heather dkk. 2004. Kontinuitas dan Perubahan dalam Sejarah Sulawesi Selatan (Penyunting Dias Pradadimara dan Muslimin A.R. Effendy). Yogyakarta: Ombak.

Koentjaraningrat, 1980. Manusia dan Kebudayaan di Indonesia. Jakarta: Djambatan.

Mahfud, Choirul. 2013. Manifesto Politik Tionghoa di Indonesia. Yogyakarta: Pustaka Pelajar.

Muhammad, As'adi. 2011. Membaca Karakter Orang Berdasarkan Etnisnya. Jogjakarta: Najah. 
Nurhayati, N. (2018). Assimilating Indonesia Chinese Muslim in Makassar (1967-1997). Yupa: Historical Studies Journal, 2(1), 1-12. https://doi.org/10.30872/yupa.v2i1.111

Rosmini, dkk. 2016. Geliat Keberagamaan Moderat Komunitas Muslim Tionghoa: (Studi Kontribusi Pengkajian IslamIntensif dalam Keberagamaan Moderat Muslim Tionghoa Kota Makassar). Makassar: PKBM rumah buku carabaca.

Sjamsudin, Helius. 2007. Metodologi Sejarah. Yogjakarta: Ombak.

Soyomukti, Nurani. 2012. Soekarno \& Cina. Jogjakarta: Garasi.

Wirawan, Yerri. 2008. Sejarah Masyarakat Tionghoa Makassar dari Abad ke-17 hingga ke-20. Jakarta: Kepustakaan populer Gramedia.

Yuanzhi, Kong. 2000. Muslim Tionghoa Cheng Ho: Misteri Perjalanan Muhibah di Nusantara. Jakarta: Pustaka Populer Obor. 